wird die hemmende Wirkung; des $A$ conitins sehwächer, lässt sish aber nicht verschwinden, und geht dann in Erregung über: Nach durchschneidung des Rückenmarks und der beiderseitigen Halssympathici ist die hemmende Wirkung ganz verschwunden und es tritt nur Erregung auf. Diese Erregung besteht-nur aus der Vergrösserung der Amplitüde.

Interessanterweise wurde bei den obigén Versuchen beobachtet, dass die Erfegung des sympathischen Zentrums ausser dem Rückenmark teils auf dem Wege über den Halssympathicus auf den Dünndarm geleitet wird.

Ferner bei Durchschneidung des Rückenmarks, der Vagi und Halssympathici übt Aconitin auf die Dünndarmbewegung keinen Einfluss mehr aús. Nach der Vagotomie und zugleich Nicotinbepinselung des Ggl. coeliacum und Ggl. mesentericum superius tritt die hemmende Wirkung des Aconitins nicht mehr auf und eine Erregung, die nur aus dem Ansteigen des Tonus besteht, wird beobachtet.

Die obigen Tatsachen scheinen dafür zu sprechen, dass Aconitin in den Seitenventrikel injiziert, in kleineren Mengen hauptsächlich auf das sympathische dünndarmhemmende Zentrum und in grösseren Mengen daneben auf das parasympathisohe dünndarmerregend Zentrum erregend wirkt. Zugleich wurde hier meine schon berichtete Anschauung bestātigt, đass die Erregung des Vagus eine Zunahme der Amplitủe der Dünndarmbewegung bedingt, während eine solche des Spinalparasympathikus zu einem Ansteigen des Tonus führt.

(Autoreferat)

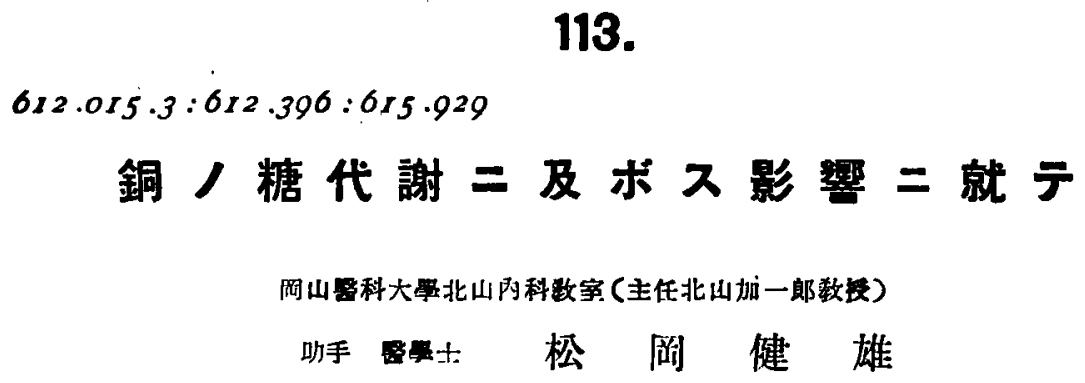

[昭和 17 年 7 月 18 日受稿]

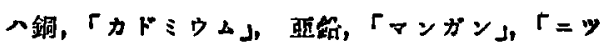

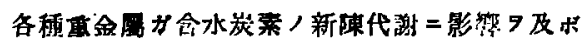

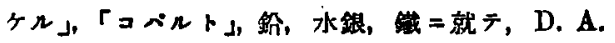

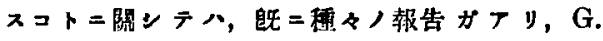
Bertrand, M. Macheboenf') 及ピ F. Hendrych, H. Weden2)ハ「=ツタル」,「コバルト」二就テ,

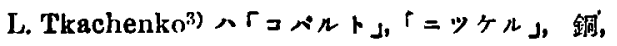

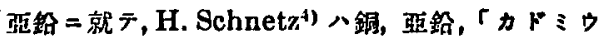

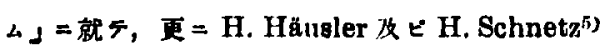

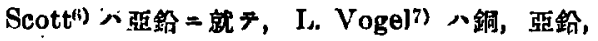

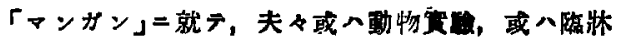

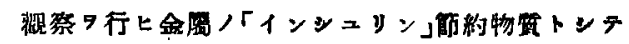

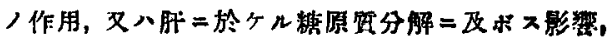

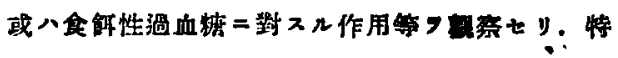
二銅に就テ八前钯ノ他 $=$ H, Handovsky ${ }^{8}$ )八家 


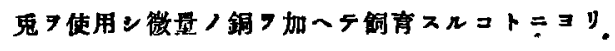

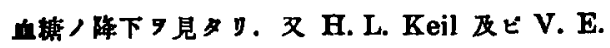

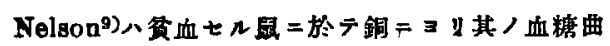

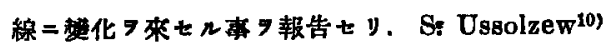

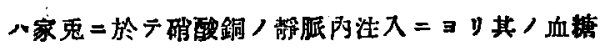

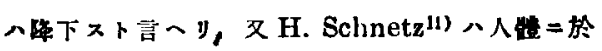

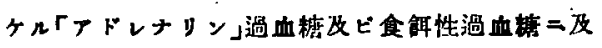

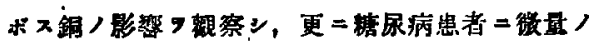

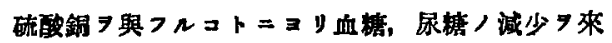
ン且使用「インシニリン」最 9 管約ン得ル事 7 報告

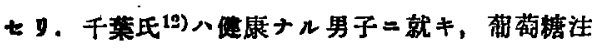

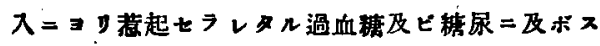

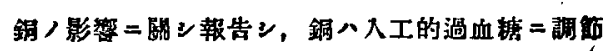

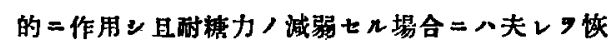
得若クハ无進センムル作用ナリト言へリ。

而ンテ以上ノ諸家ノ宾驗成綪ハ必ズルモ常ニ一 政ン居ラス゚.

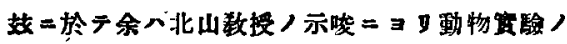

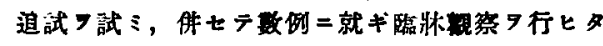
ルタ以テ報告セントス。

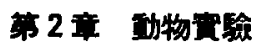

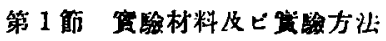

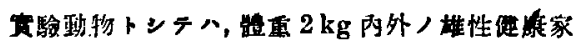

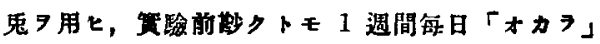

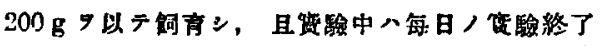

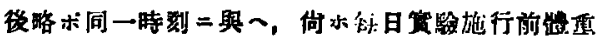
测定七y.

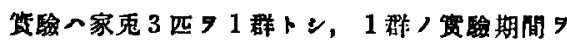
9 日間トシ，其八期間 92 期=分千，前期八最初

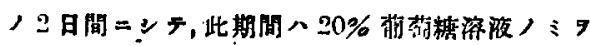

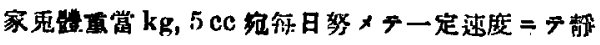

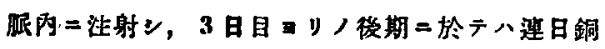

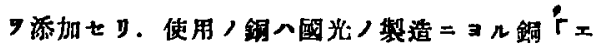

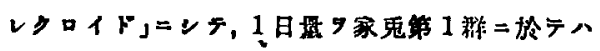

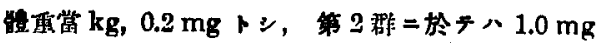

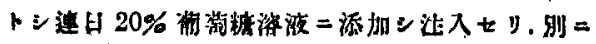

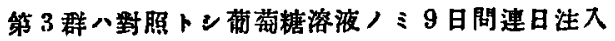
七り。何水是等蜜驗ノ一部 7 剔脾家鬼二就キ宽施

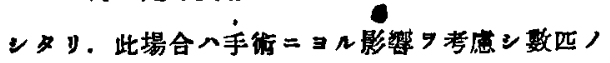

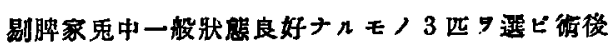
6 日目ヨy变駩二使用七y。

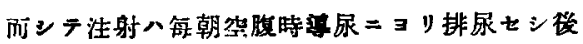

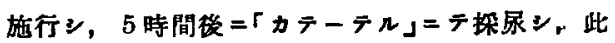
間籍ノ下=「コルベン」ヨ置キテ受ケタル放尿ト合 シ，展量，反庶，比重 7 湘定ン，更二其／尿卜同

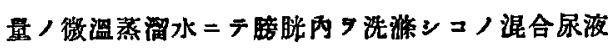

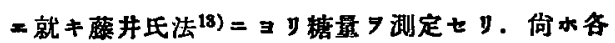

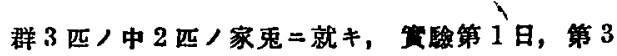
日，第 6 日，第 9 日ノ 4 回 Hagedorn-Jensen 氏

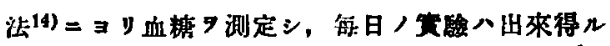

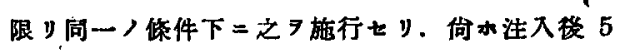

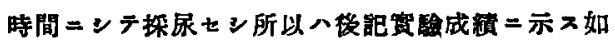

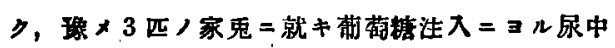

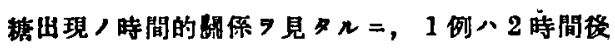
既二榶 9 證明七ズ，第 2 例八 3 時間输之》證明七

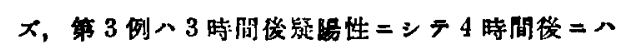
さフ證明セザリンニ由几。

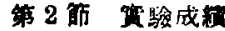

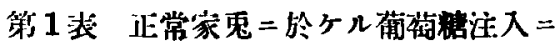
依儿症中糖出現八時間的關係

\begin{tabular}{|c|c|c|c|c|c|c|}
\hline 家 & 注入前 & $\begin{array}{c}\text { 後 } \\
\text { 1時間 }\end{array}$ & 2時間 & 3時間 & 4時間 & 5時間 \\
\hline I & - & H & - & - & - & - \\
\hline II & - & $H$ & + & 一 & - & - \\
\hline III & - & $H$ & + & \pm & $\rightarrow$ & - \\
\hline
\end{tabular}

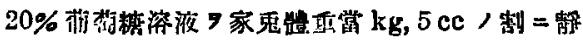
脈內 溡入スル

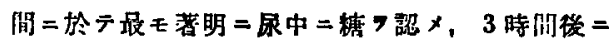
於テ八㮖 $=$ 痕跡 7 止么二過ギズ，4時間以後二於 テヘ全ク之7見ズ。依ツテ上毁ノ如ク各传驗二於

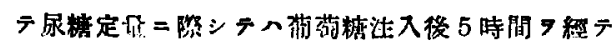
珠层七り。 
第 1 項 正常家兔䆓脸

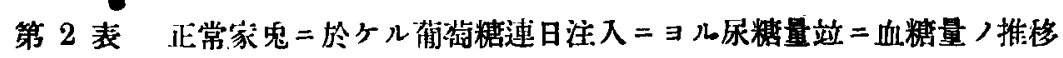

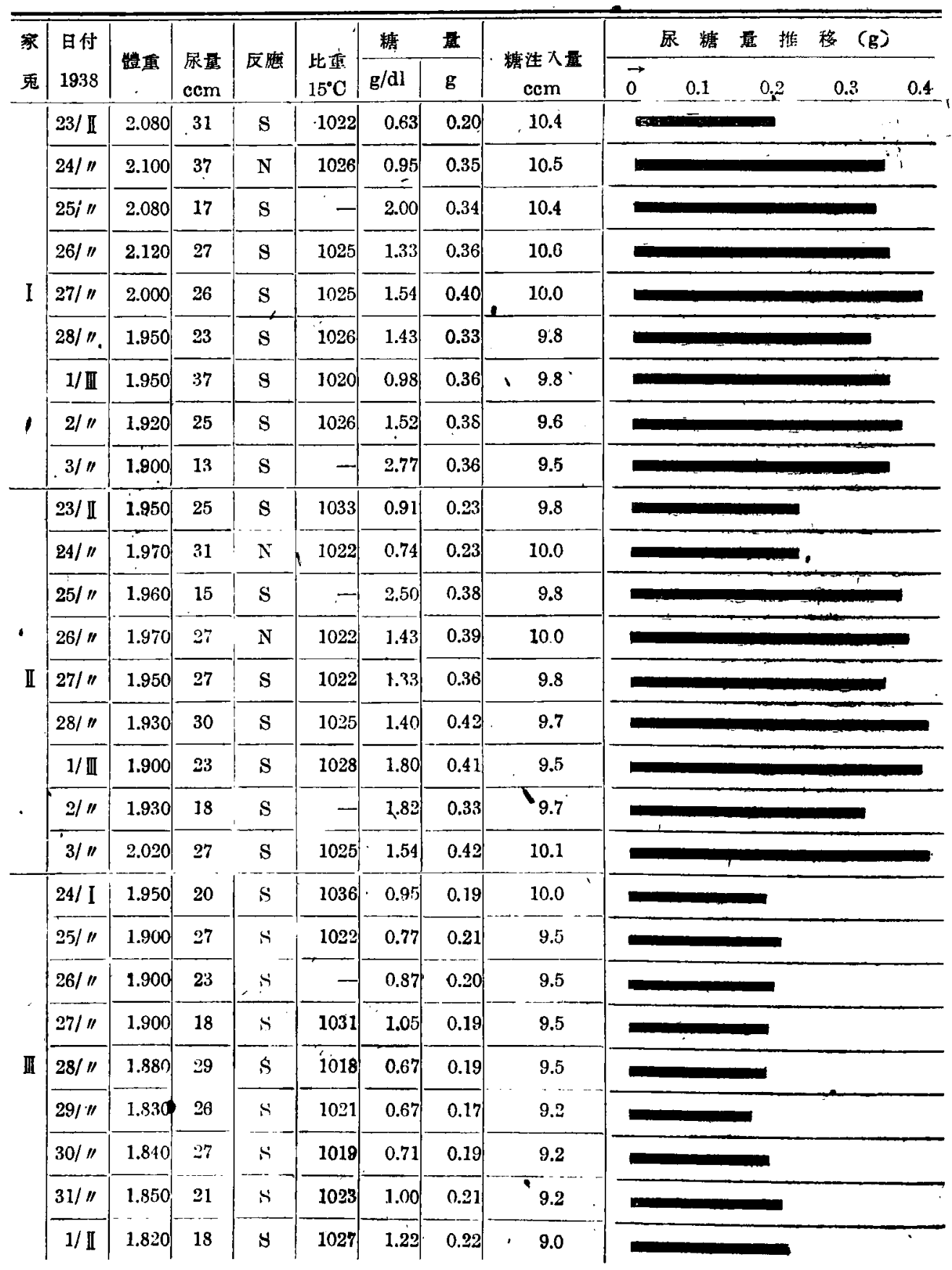




\begin{tabular}{|c|c|c|c|c|c|c|c|}
\hline \multirow{2}{*}{$\begin{array}{l}\text { 家 } \\
\text { 鬼 }\end{array}$} & \multirow{2}{*}{$\begin{array}{c}\text { 日 附 } \\
1938\end{array}$} & \multicolumn{2}{|c|}{ 血 } & 啸 & \multicolumn{2}{|c|}{$\mathrm{g} / \mathrm{dl}$} & \multirow{2}{*}{$\begin{array}{c}\text { 糖注入量 } \\
\text { cc }\end{array}$} \\
\hline & & 泩 入 前 & 倦 30 分 & " 1 時間 & " 2 時間 & " 3 時間 & \\
\hline \multirow{4}{*}{ I } & $23 /$ II & 0.090 & 0.270 & $0: 204$ & 0.129 & 0.102 & 10.4 \\
\hline & $25 / 11$ & 0.111 & 0.255 & 0.209 & 0.120 & 0.097 & $"$ \\
\hline & $28 / 11$ & 0.088 & 0.260 & 0.200 & 0.136 & 0.104 & 10.0 \\
\hline & $3 /$ III & 0.099 & 0.268 & 0.215 & 0.141 & 0.113 & 9.5 \\
\hline \multirow{4}{*}{ I } & $23 / \mathbf{I}$ & 0.115 & 0.323 & 0.272 & 0.186 & 0.125 & 9.8 \\
\hline & $25 / 11$ & 0.125 & 0.329 & 0.331 & 0.284 & 0.199 & " \\
\hline & $28 / \|$ & 0.131 & 0.336 & 0.288 & 0.230 & 0.145 & 9.7 \\
\hline & $3 /$ II & 0.119 & 0.319 & 0.280 & 0.197 & 0.120 & 10.1 \\
\hline
\end{tabular}

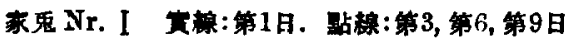

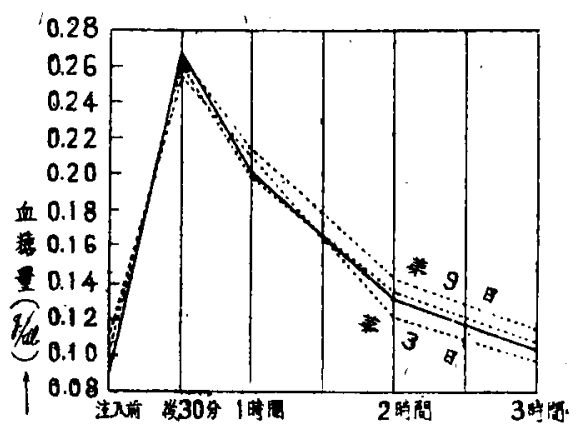

家鬼 Nr. II

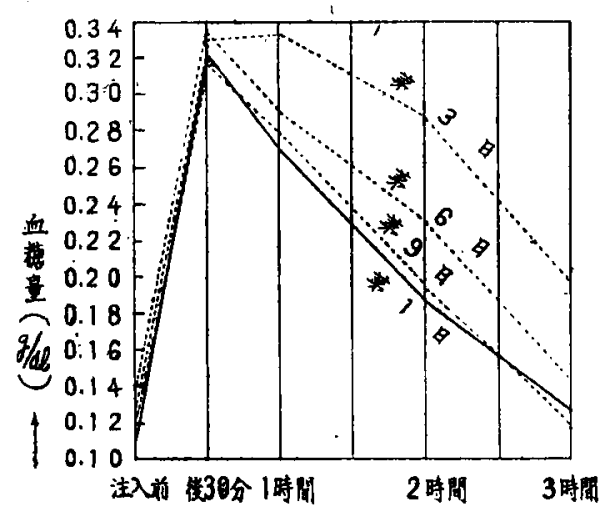

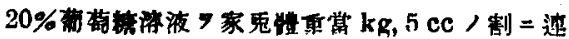

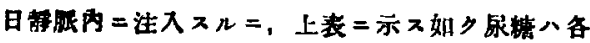

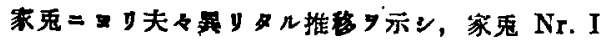

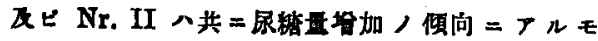

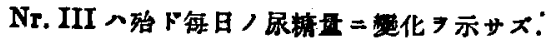

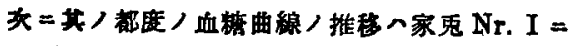

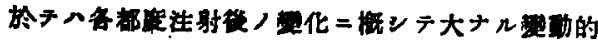

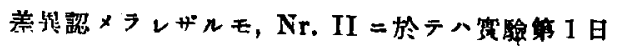

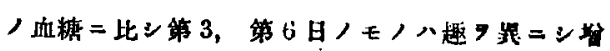
加ン，第 9 日ノモノ八初四，場合二近シ，郎チ上:

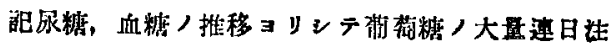

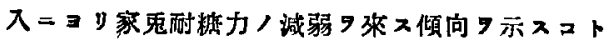

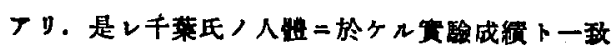
ty. 


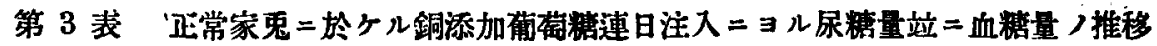

1. 铜量賞 $\mathrm{kg} 0.2 \mathrm{mg}$, 埸合

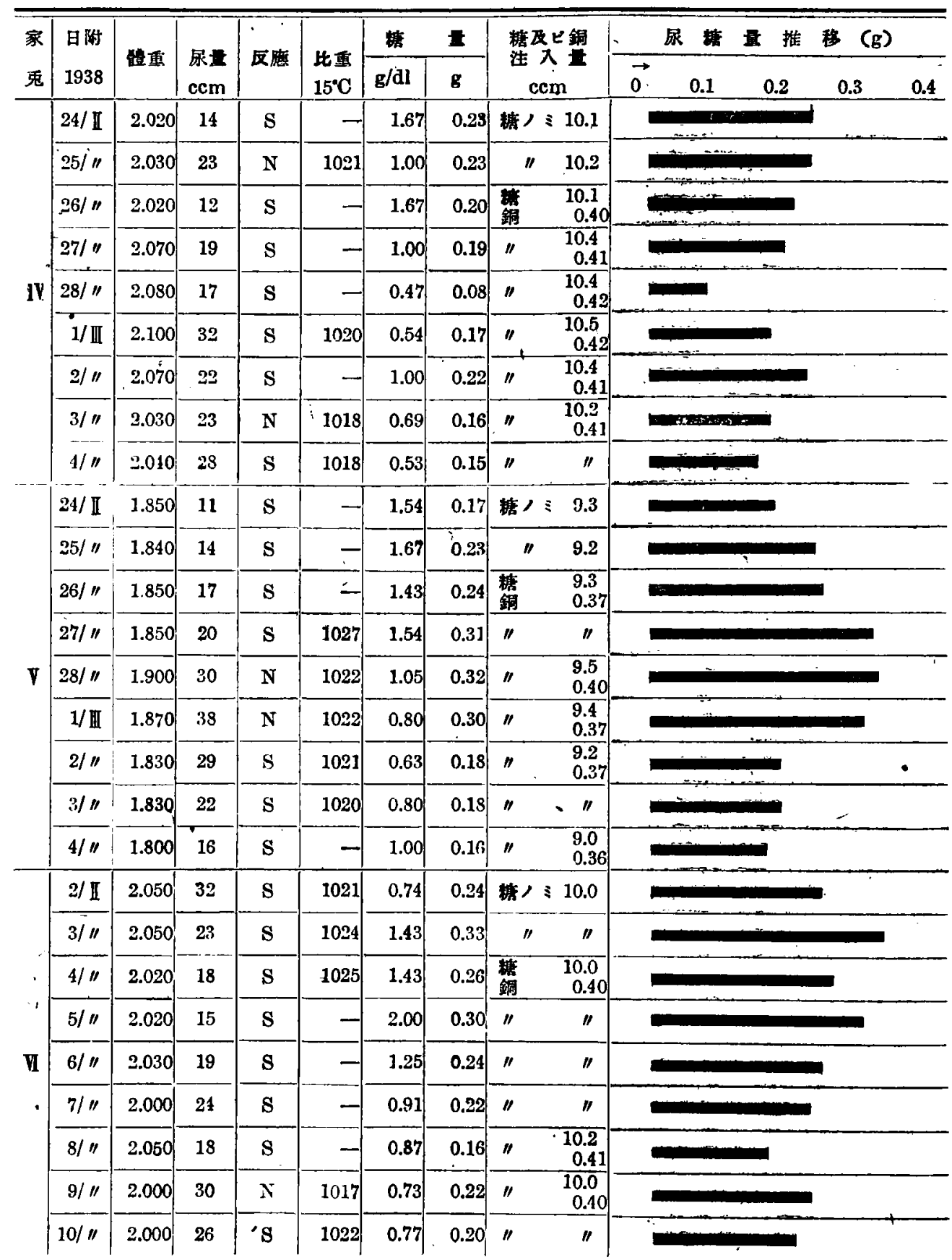




\begin{tabular}{|c|c|c|c|c|c|c|c|}
\hline 家 & 日坿 & 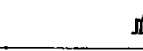 & $\therefore$ & $\cdot$ & & & 糖及ビ銅 \\
\hline 鬼 & 1938 & 洗 入前 & 棪 30 分 & "/ I時間 & " 2 時間 & $" l 3$ 時閉 & ce \\
\hline \multirow{4}{*}{ IV } & $24 /$ II & 0.097 & 0.286 & 0.262 & 0.197 & 0.136 & 糖ノミ10.1 \\
\hline & $26 / 11$ & 0.111 & 0.284 & 0.209 & 0.145 & 0.104 & $\begin{array}{lc}\text { 糖 } & 10.1 \\
\text { 銅 } & 0.40 \\
\end{array}$ \\
\hline & $1 / \mathbb{I I}$ & - 0.084 & 0.280 & 0.181 & 0.099 & 0.101 & $\begin{array}{lc}\prime & 10.5 \\
& 0.11 \\
\end{array}$ \\
\hline & $4 / 11$ & 0.117 & 0.276 & 0.211 & 0.131 & 0.102 & $\begin{array}{r}10.2 \\
0.40 \\
\end{array}$ \\
\hline \multirow{4}{*}{$\nabla$} & $24 / I I$ & $0.110^{\circ}$ & 0.276 & 0.154 & 0.106 & 0.099 & 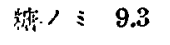 \\
\hline & $26 / 1 /$ & 0.113 & 0.222 & 0.150 & 0.108 & 0.101 & $\begin{array}{c}9.3 \\
0.37 \\
\end{array}$ \\
\hline & $1 / \mathbb{I I}$ & 0.104 & 0.211 & 0.127 & 0.097 & 0.097 & $\begin{array}{l}9.4 \\
0.37 \\
\end{array}$ \\
\hline & $4 / 11$ & 0.108 & 0.219 & 0.164 & 0.104 & 0.097 & $\begin{array}{l}9.0 \\
0.36\end{array}$ \\
\hline
\end{tabular}

家鬼 Nr. IV

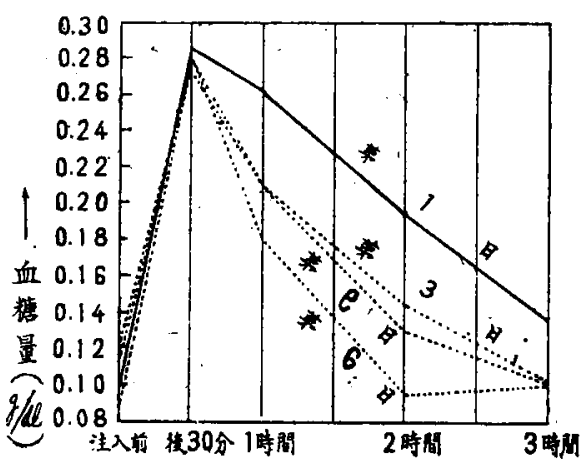

家鬼 Nr. Y 签線：第1日.點楾：第3，第6，第9日

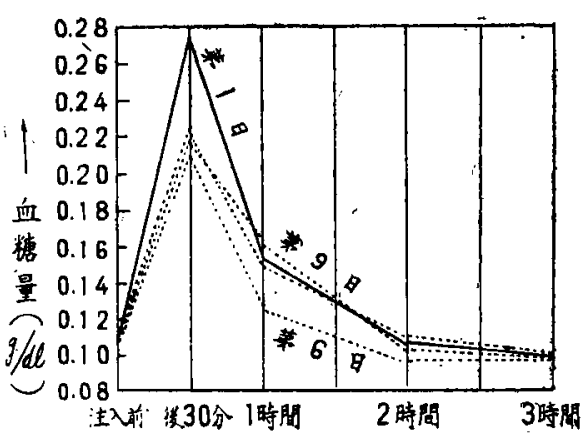

此場合八上表二示ス如ク尿涨八各象鬼二於示略

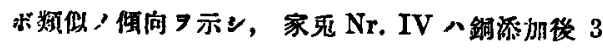

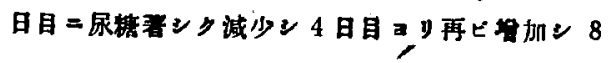

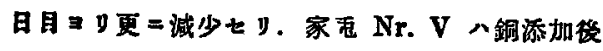

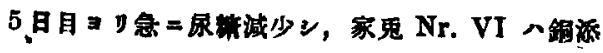

加3日日ヨy濑次娍少セり。

次二血糖曲線，推移八家鬼 Nr. IV =於テへ血

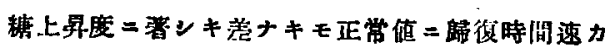

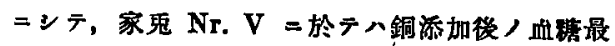
高健へ銅添加前ノ夫レニ比ン減少セり。 


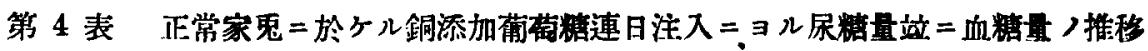
D. 銅量㗬 $\mathrm{kg} 1.0 \mathrm{mg}$, 埸合

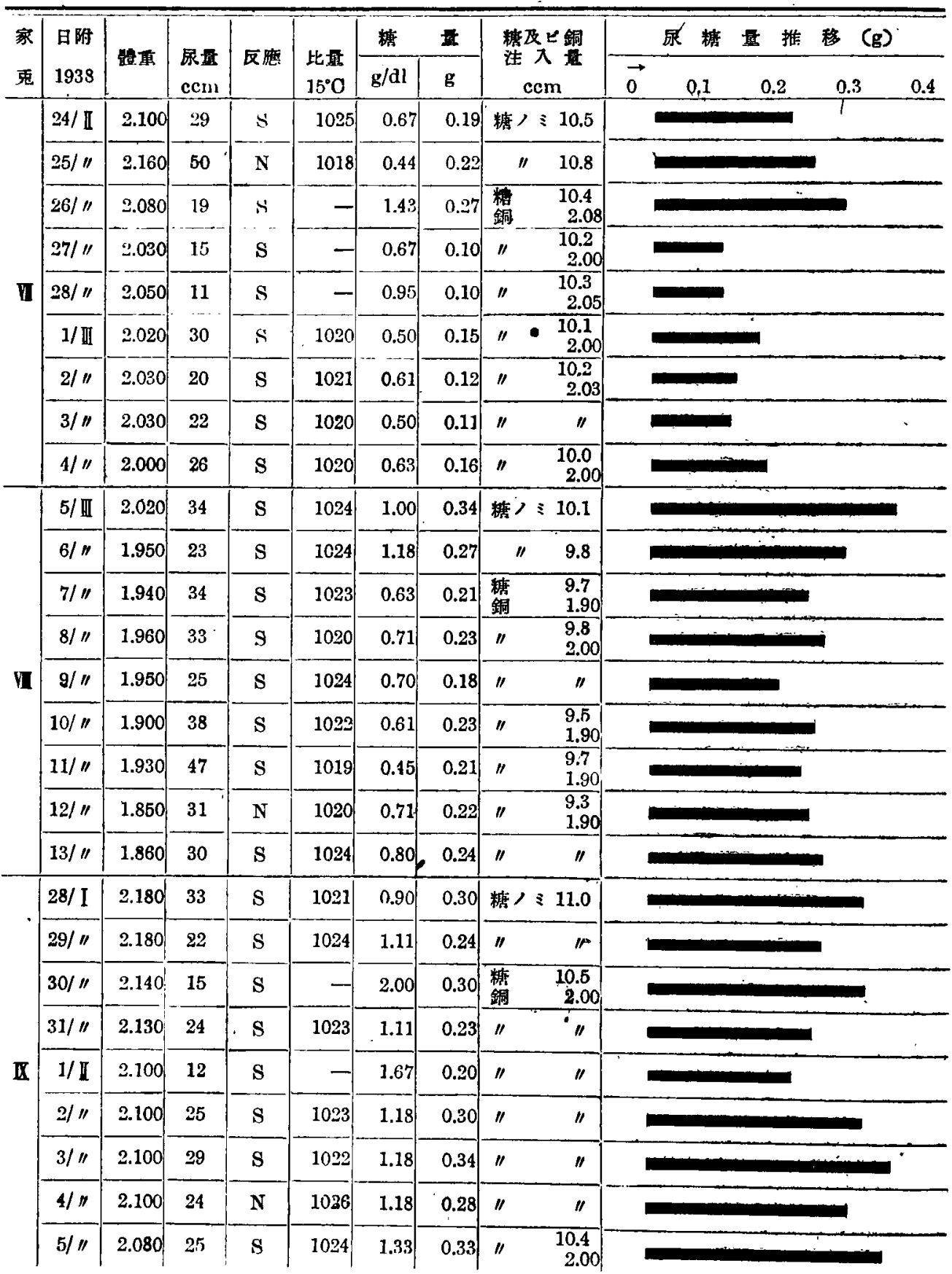




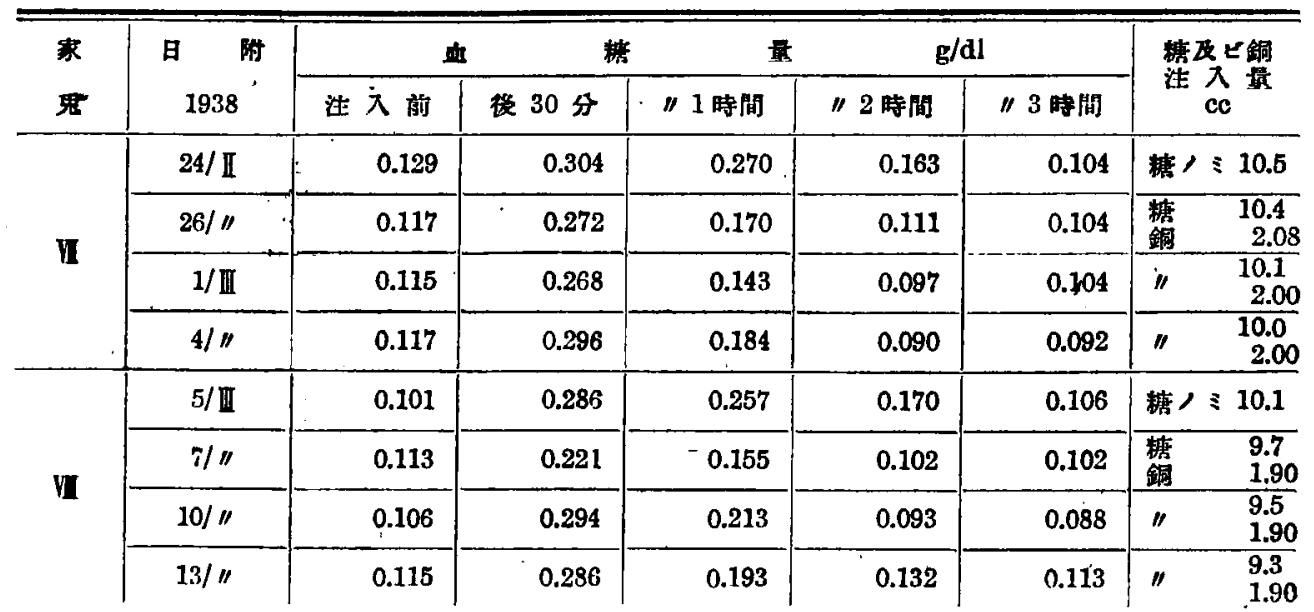

家息 Nr. V

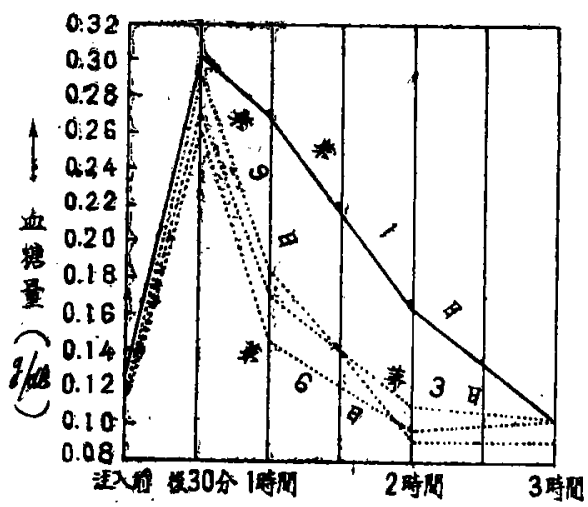

家鬼 Nr.VI

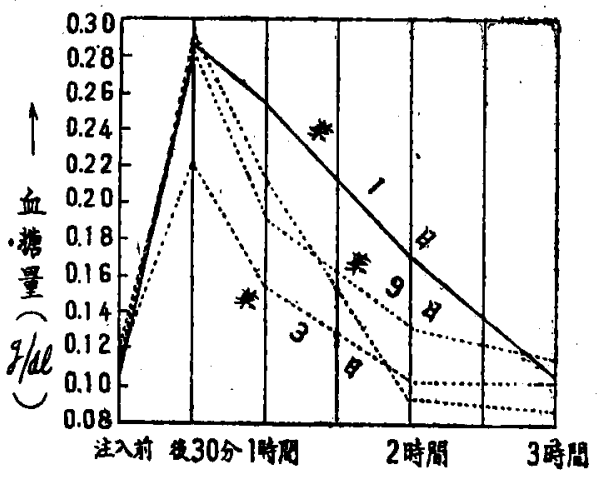

尿制量八上表二示ス如》家鬼 Nr. VII, Nr. VIII,

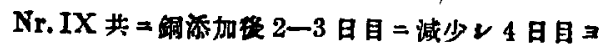

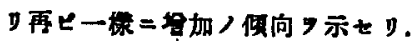

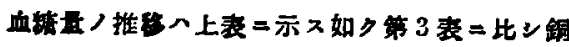

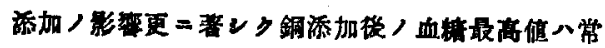

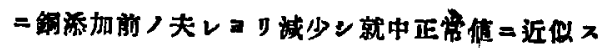

ル時間モ速カナリ。

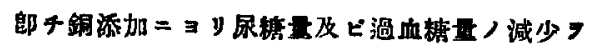

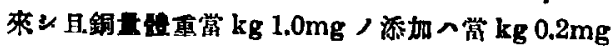

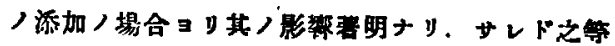

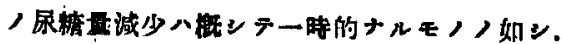




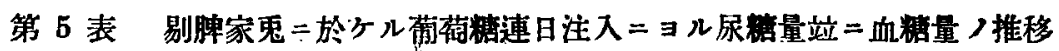

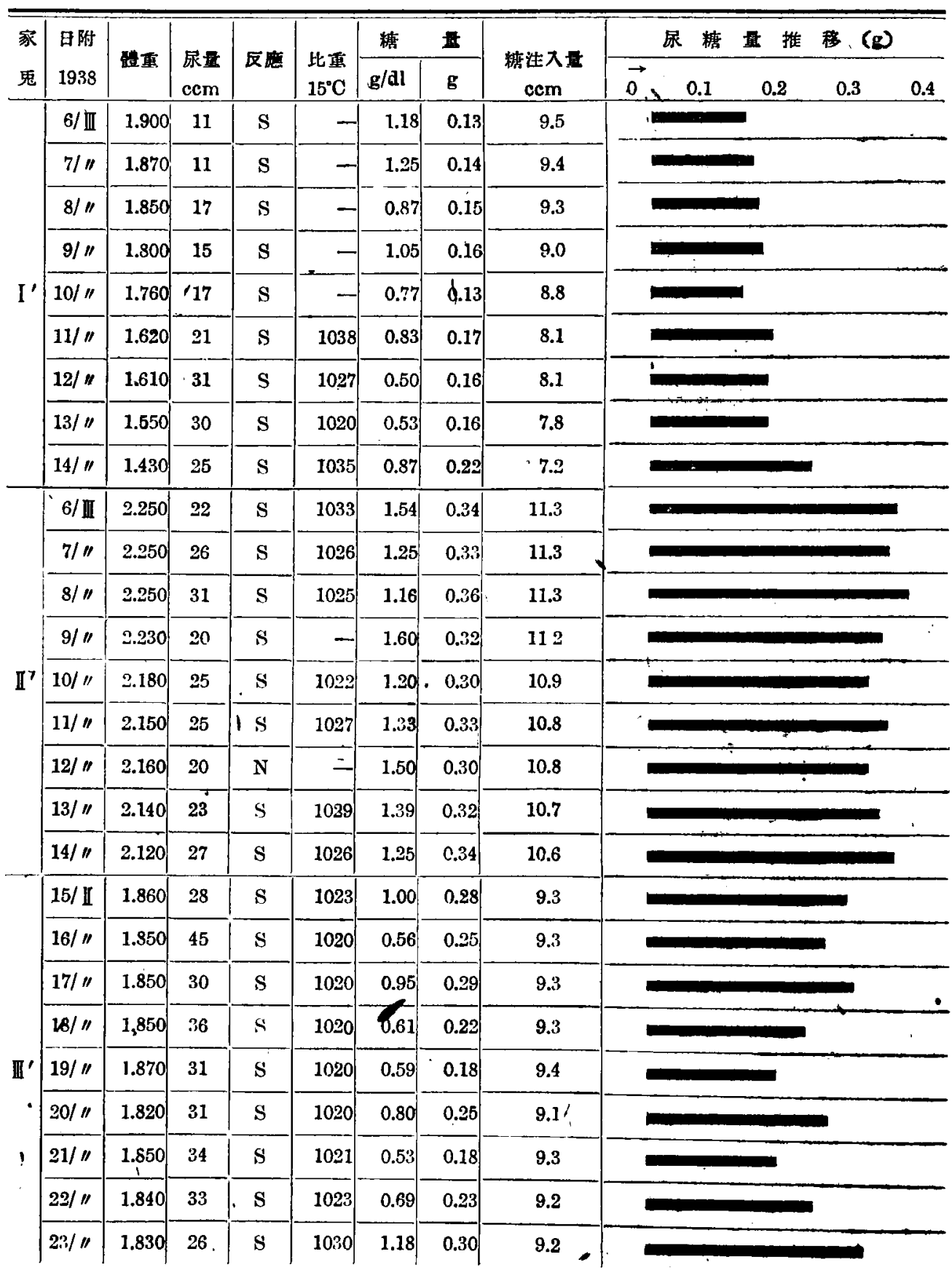




\begin{tabular}{|c|c|c|c|c|c|c|c|}
\hline \multirow{2}{*}{ 家 } & \multirow{2}{*}{$\begin{array}{c}\text { 日 }- \text { 附 } \\
1938\end{array}$} & \multicolumn{2}{|c|}{ 血 } & 量 & \multicolumn{2}{|c|}{$\mathrm{g} / \mathrm{dl}$} & \multirow{2}{*}{$\begin{array}{c}\text { 糖泩入豆 } \\
\text { cc }\end{array}$} \\
\hline & & 注 入 前 & 棪 30 分 & "I I 間 & " 2 時間 & " 3 時間 & \\
\hline \multirow{4}{*}{$I^{\prime}$} & $6 /$ III & 0.119 & 0.325 & 0.274 & $\quad 0.163$ & 0.092 & 9.5 \\
\hline & $8 / 11$ & 0.120 & 0.329 & 0.280 & 0.180 & 0.104 & 9.3 \\
\hline & $11 / 1 /$ & 0.115 & 0.338 & 0.300 & 0.190 & 0.111 & 8.1 \\
\hline & $14 / n$ & 0.122 & 0.341 & 0.290 & 0.170 & 0.113 & 7.2 \\
\hline \multirow{4}{*}{$\mathbb{I}^{\prime}$} & $6 / \mathbb{1 1}$ & 0.088 & 0.268 & 0.200 & 0.099 & 0.090 & 11.3 \\
\hline & $8 / 11$ & 0,101 & 0.251 & 0.193 & 0.120 & 0.104 & 11.3 \\
\hline & $11 / " /$ & 0.108 & 0.264 & 0.211 & 0.172 & 0.106 & 10.8 \\
\hline & $14 / " \prime$ & 0.119 & 0.292 & 0.188 & 0.134 & 0.122 & 10.6 \\
\hline
\end{tabular}

家鬼 Nr. I' 寞線：第1日.點線：第3，第6，第9日

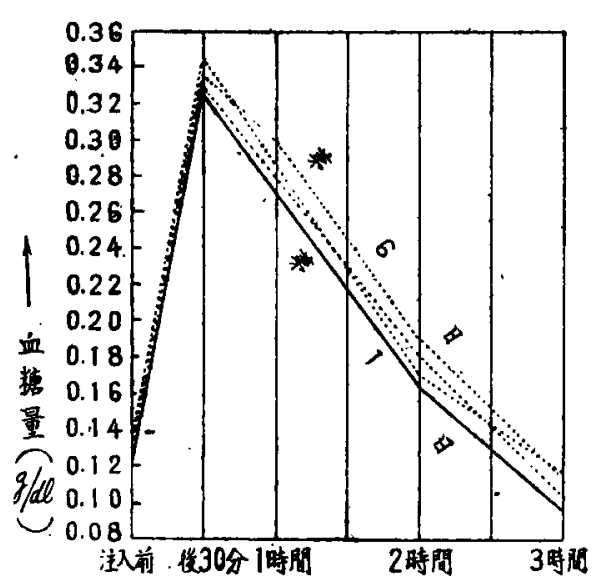

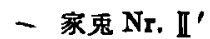

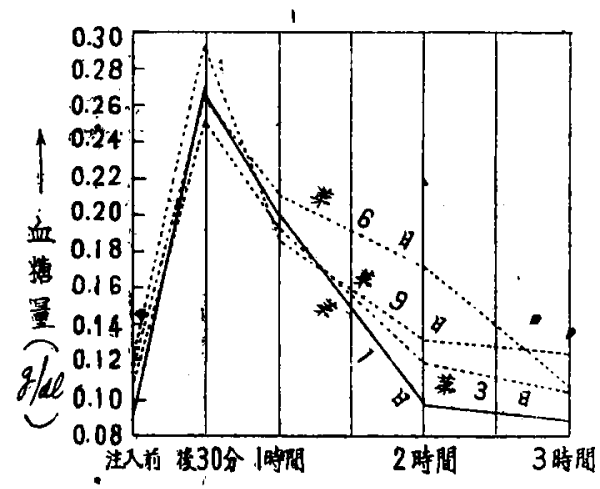

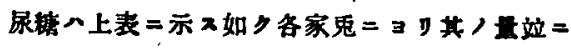

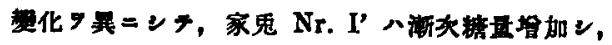

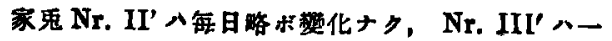

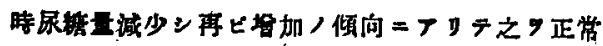

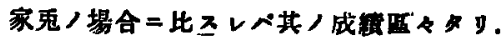

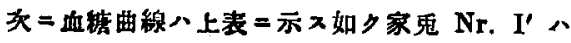

第 3，策6，第 9 日

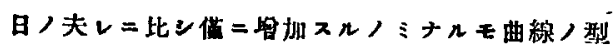

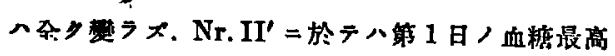
值ヨリ他日ノ夫レガ一時ハ瑊少スルモ終ニ八科々

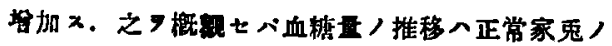
埸会卜大差 7 証メズ. 
第 6 表 剔脾家鬼二於ケル銅添加蒱萄糖連日注入 $=\Xi$ ル尿糖量站=血糖量 つ推移

銅貫當 $\mathrm{kg} 1.0 \mathrm{mg}$ /䭪合

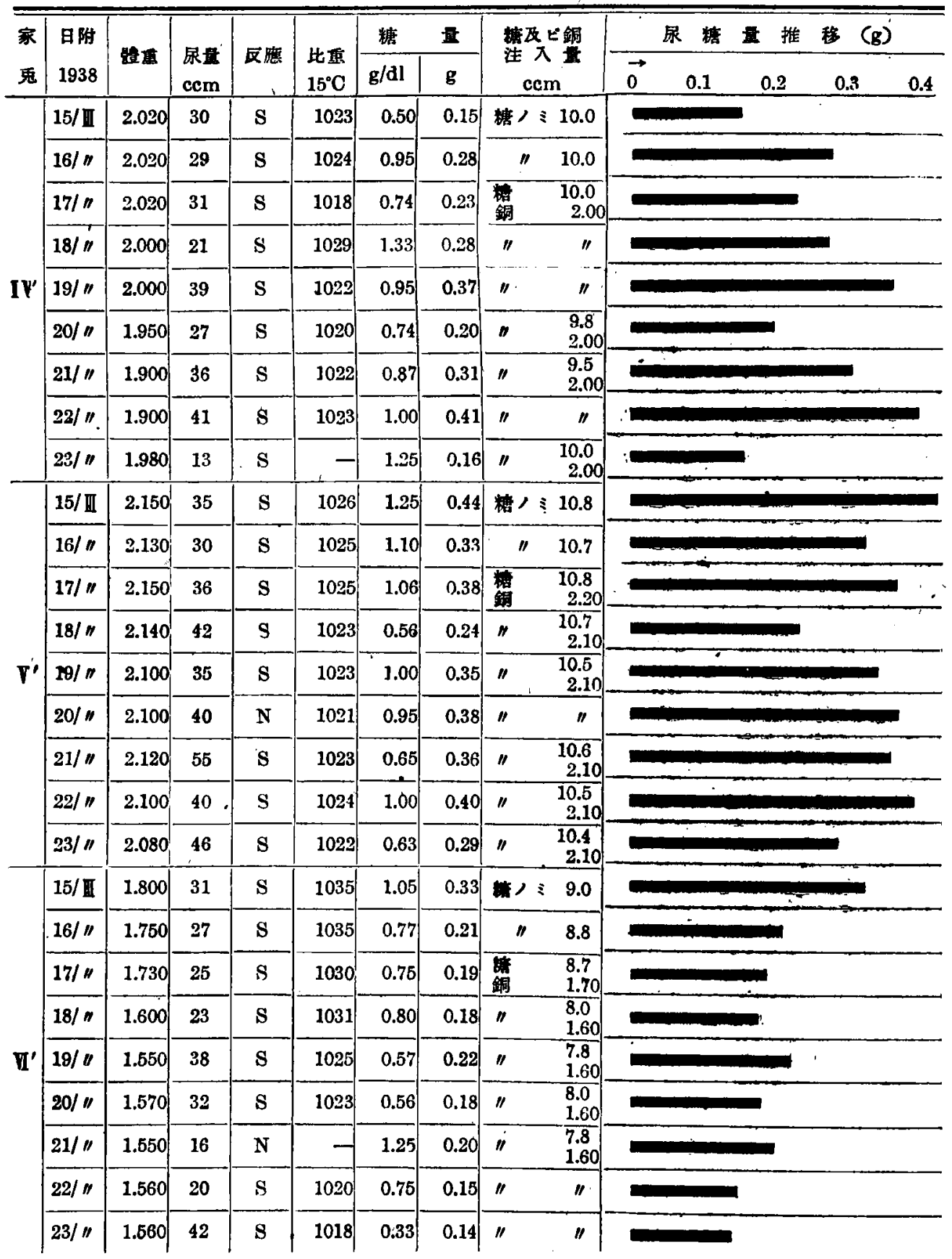




\begin{tabular}{|c|c|c|c|c|c|c|c|}
\hline \multirow{2}{*}{$\begin{array}{l}\text { 家 } \\
\text { 鬼 }\end{array}$} & \multirow{2}{*}{$\begin{array}{c}\text { 日 㨐 } \\
1938 \\
\end{array}$} & \multicolumn{2}{|c|}{ 血 } & 瞊 & \multicolumn{2}{|c|}{$\mathrm{g} / \mathrm{dl}$} & \multirow{2}{*}{$\begin{array}{c}\text { 糖及七銅 } \\
\text { 注 } \\
\text { cc } \\
\end{array}$} \\
\hline & & 注 入 前 & 後 30 分. & " 1 時間 & "I2時間 & " 3 時問 & \\
\hline \multirow{4}{*}{$\begin{array}{r}\text { IY' } \\
:\end{array}$} & $15 / \mathbb{I I}$ & 0.115 & 0.259 & 0.154 & 0.101 & 0.106 & 糖 \\
\hline & $17 / 1 /$ & 0.115 & 0.272 & 0.161 & 0.115 & 0.113 & $\begin{array}{lc}\text { 糖 } & 10.0 \\
\text { 銅 } & 2.00 \\
\end{array}$ \\
\hline & $20 / 1 /$ & 0.115 & 0.230 & 0.150 & 0.101 & 0.102 & $\begin{array}{ll}\prime \prime & 9.8 \\
& 2.00 \\
\end{array}$ \\
\hline & $23 / 1 "$ & 0.115 & 0.241 & 0.168 & 0.110 & 0.111 & $\begin{array}{ll}\prime \prime & 10.0 \\
& 2.00 \\
\end{array}$ \\
\hline \multirow{4}{*}{$\mathbf{Y}^{\prime}$} & $15 /$ III & 0.106 & 0.259 & 0.197 & 0.120 & 0.097 & 糖 \\
\hline & $17 / 1 /$ & 0.122 & 0.251 & 0.181 & 0.131 & 0.122 & $\begin{array}{cc}\text { 䌅 } & 10.0 \\
\text { 銅 } & 2.00 \\
\end{array}$ \\
\hline & $20 / 11$ & 0.117 & 0.262 & 0.208 & 0.145 & 0.106 & $\begin{array}{ll}* & 105 \\
& 2.10 \\
\end{array}$ \\
\hline & $23 / 11$ & 0.124 & ' 0.251 & 0.190 & 0.141 & 0.099 & $\begin{array}{c}10.4 \\
2.10\end{array}$ \\
\hline
\end{tabular}

家鬼 Nr. IV'寞線：第 1 日

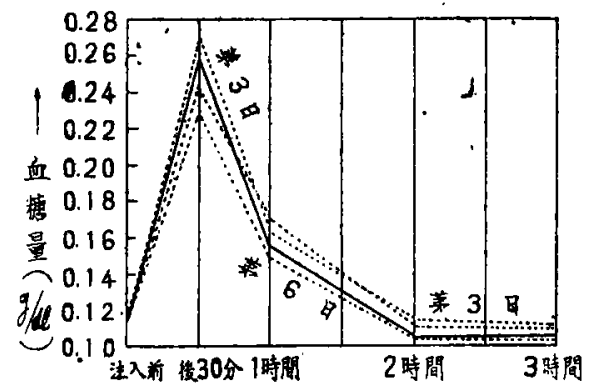

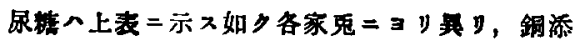

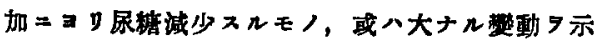
シッッ掼加スルモノフリテー定ノ傾向 ラ示サズ.

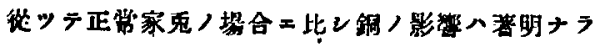
x.

血糖曲線八上表 $=$ 示 如夕家鬼 Nr. IV', Nr.

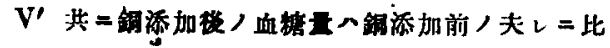
ン必ホレモ減少ン居ラズ. 即チ正常家鬼ノ場合卜

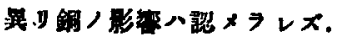

\section{牙了年 臨牃覞察}

方法

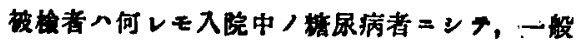

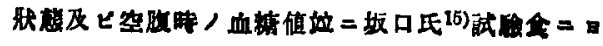

家冤 Nr. $V^{\prime}$

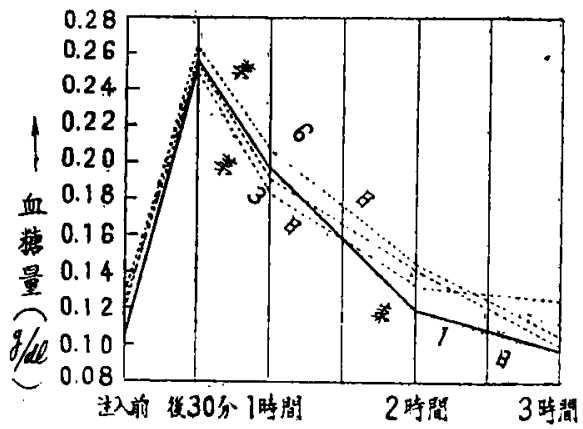

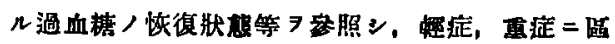
䟝ン察䐘

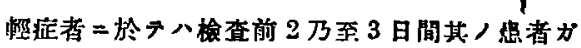

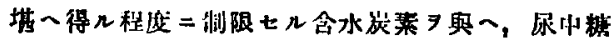

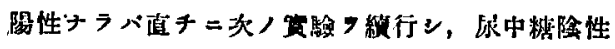
ナラバ含水炭慗 9 燳量シ糖尿陽性トナルニ至り次

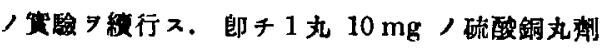
(銅最 $2.5 \mathrm{mg}$ )9每日6乃至 8 筒的口投舆ン血

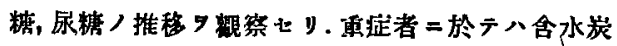

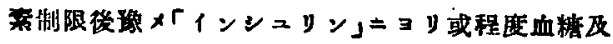

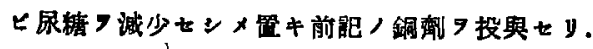

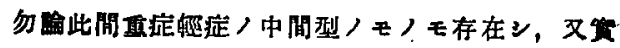

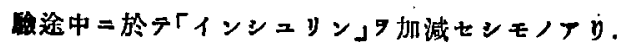

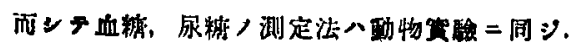


成綡

第 7 表 銅ノ糖尿病者ノ血糖站二尿糖二及尔ス影觜

\begin{tabular}{|c|c|c|c|c|c|c|c|c|c|c|c|c|}
\hline \multirow{2}{*}{ 畨 } & \multirow{2}{*}{$\begin{array}{l}\text { 姓 } \\
\text { 性 } \\
\text { 年 }\end{array}$} & \multirow{2}{*}{ 然 } & \multirow[b]{2}{*}{ 檢查日 } & \multirow[b]{2}{*}{ 試驗別 } & \multicolumn{2}{|c|}{ 卹 } & \multicolumn{2}{|l|}{ 潇 } & \multicolumn{3}{|c|}{ 量 $(\mathrm{mg} \%)$} & \multirow{2}{*}{ 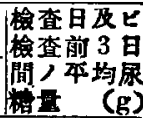 } \\
\hline & & & & & 全前 & 啳30分 & 1時闍 & $\begin{array}{l}1.5 \\
\text { 時間 }\end{array}$ & 2 时間 & \begin{tabular}{|c|}
2.5 \\
時間
\end{tabular} & 3時問 & \\
\hline \multirow{3}{*}{1} & 杉O & 重 & $20 / \mathbb{X} \quad 1937$ & 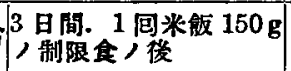 & 244 & 258 & 292 & 272 & 278 & 278 & 290 & 21.94 \\
\hline & q & & $25 / \mathbf{X} \quad \prime$ & 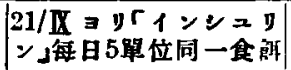 & 308 & 336 & 318 & 300 & 264 & 301 & 292 & $38 \dot{8} .68$ \\
\hline & 21 & 症 & $1 / X \quad "$ & 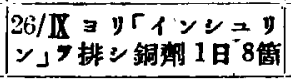 & 434 & 482 & 482 & 444 & 434 & 382 & 364 & 34.37 \\
\hline \multirow{3}{*}{2} & \multirow[t]{3}{*}{ 大 } & & $28 / \mathbb{X} \quad 1937$ & 3 日間. 1 间米饭 $300 \mathrm{~g}$ & 182 & 313 & 251 & 264 & 298 & 213 & 186 & 0.77 \\
\hline & & STs & $1 / X \quad \prime \prime$ & 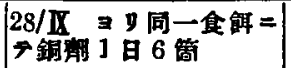 & & & & & & & & 0.27 \\
\hline & & 拉 & $11 / X$ & 同上 & & & & & & & & $(-)$ \\
\hline \multirow{4}{*}{3} & \multirow{4}{*}{$4 \rho$} & \multirow{4}{*}{ 重 } & $20 / \mathbf{X} \cdot 1937$ & $\left|\begin{array}{l}3 \text { 日間. I回米仮 } 150 \mathrm{~g} \text { 及 } \\
\text { インンンンン」單位 }\end{array}\right|$ & 272 & 282 & 278 & 296 & 286 & 282 & 304 & 27.32 \\
\hline & & & $27 / \mathrm{X} \quad 1$ & 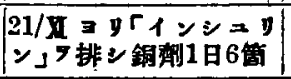 & 328 & 430 & 480 & 464 & 444 & 372 & 386 & 29.00 \\
\hline & & & $5 / 1$ & 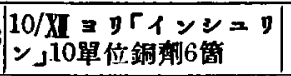 & 176 & 282 & 344 & -300 & 290 & 286 & 248 & 3.80 \\
\hline & & & $17 / I \quad$ & 同上 & $' 146$ & 188 & 262 & 266 & 251 & 236 & 213 & 3.19 \\
\hline \multirow{3}{*}{4} & \multirow{3}{*}{$\begin{array}{c}\wedge 0 \\
8 \\
63\end{array}$} & \multirow{3}{*}{ 证 } & 4/XI 1937 & 連日酱通金ノ杸 & 168 & 222 & 286 & 257 & $25:$ & 224 & 222 & 5.92 \\
\hline & & & $14 / X \quad "$ & 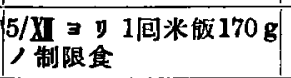 & & & & & & & & 0.24 \\
\hline & & & $20 / \mathrm{X} \quad 1$ & 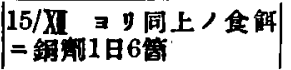 & & & & & & & & 0.25 \\
\hline \multirow{5}{*}{5} & & \multirow[b]{2}{*}{ 中 } & \multirow{2}{*}{$\mid \begin{array}{ll}11 / I & 1938 \\
17 / I \quad "\end{array}$} & 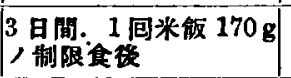 & 161 & 266 & 280 & 272 & 253 & 247 & 241 & 19.00 \\
\hline & $\begin{array}{c}9 \\
1 \\
1\end{array}$ & & & 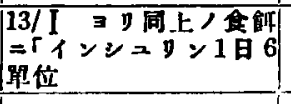 & 152 & 215 & 240 & 234 & 222 & 199 & 190 & 10.15 \\
\hline & $\delta$ & 笋 & $8 / \mathbb{I} \quad / 1$ & 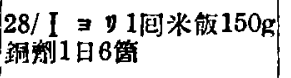 & & & & & & & & 19.85 \\
\hline & & & $18 / I$ & 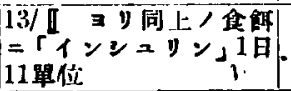 & & & & & & & & 4.20 \\
\hline & 60 & 症 & $2 /$ III $\quad "$ & 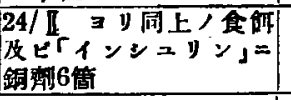 & 104 & 200 & 228 & 224 & 177 & 168 & 140 & 0.50 \\
\hline \multirow{2}{*}{6} & \multirow{2}{*}{\begin{tabular}{c|} 
押O \\
6 \\
73
\end{tabular}} & \multirow{2}{*}{ 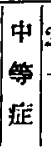 } & $25 / \mathrm{W}, 1938$ & 3，旦间. 1 回米食 $170 \mathrm{~g}$ & 157 & 213 & 247 & 243 & 247 & 221 & 193 & $( \pm)$ \\
\hline & & & $\mathbf{3} / \mathbf{Y} \quad 1$ & 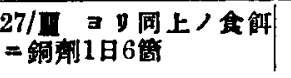 & $13 \theta$ & 240 & 266 & 224 & 193 & 161 & 146 & $( \pm)$ \\
\hline
\end{tabular}

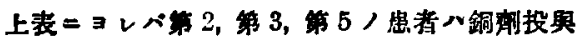

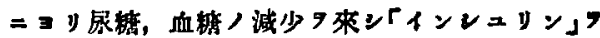
或程度皦的ン得几モ，第 1 , 第 4 ，第 $6=$ 於テ八銅

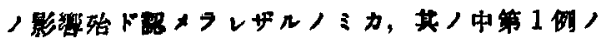

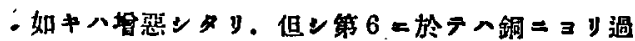

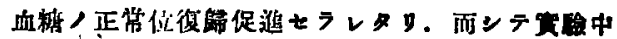

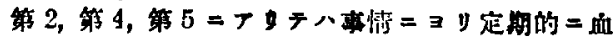

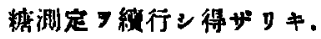




\section{第4章億括及比考按}

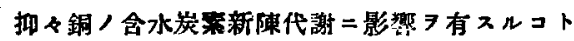
二就テハ既ニ報告セラレシ所ニシテ，1927年 L.

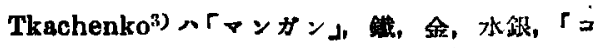

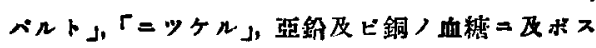

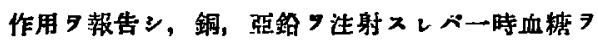
降下ン且其/場合「インンュリン」ニ附加シ注射 レペ「インンンリン」ノ作用 9 增强スルモ、練返ン 注射 7 行フ時ハ中毒現象

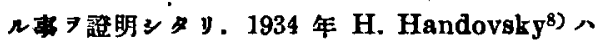

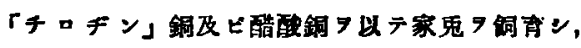

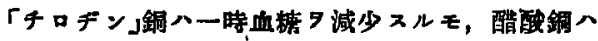
血糖二数り何等作用セザル事 7 報告セり，而ンテ

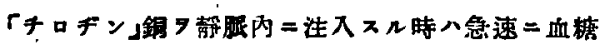
ノ上年ョ來スト言へy.更二同氏ハ「インンメリン」

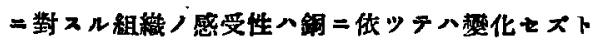
絬論七り，同年 H. L. Keil Z゙ビ V. E. Nelson?)

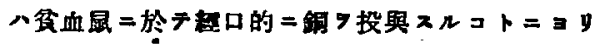
鼠ノ血瞊曲線が鋼投與前二比ン上昇少キコトラ坏

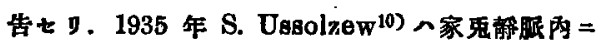
码酸銅フ注入ン血殸ノ降下゙ス几ラ證明をy，同年

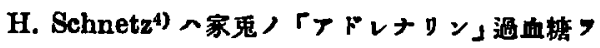
銅ニョリ抑制ン得ル事フ證明ン更二同氏ハH.

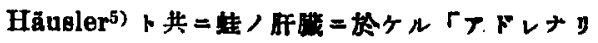

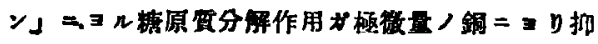

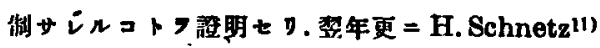

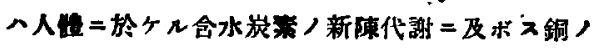

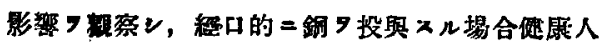

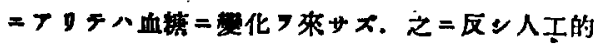

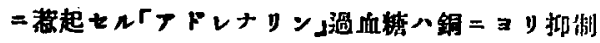

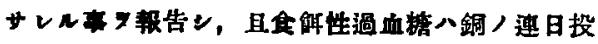

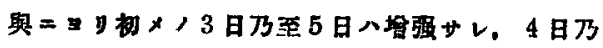

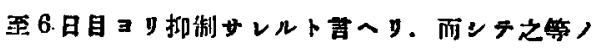

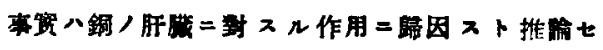

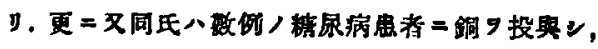

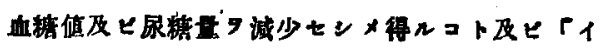

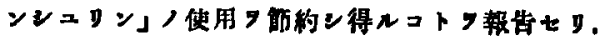

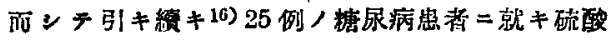

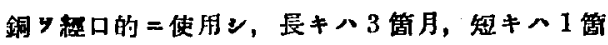

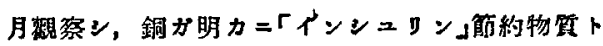
ンテ作用ス几事 千等氏 ${ }^{12)}$ 八硫酸銅溶液 7 使用シ，健康ナ几成人男

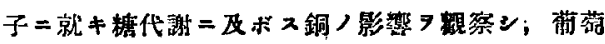
糖喵队输入 =

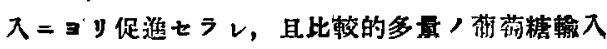
ショリテ減弱センメラレタル個體ノ耐糖力八鎘二 コリ恢得若クハ充進七ラルト結諭七り.

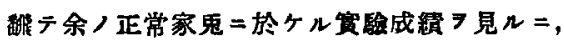

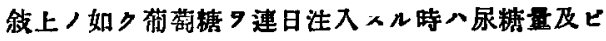
血糖盘八共二增加

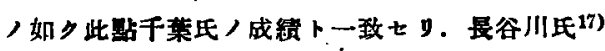
モ又犬

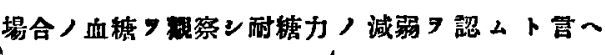
y.

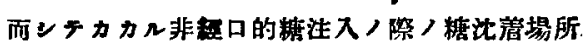

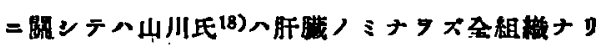

ト諭紫セり。

上田氏 ${ }^{19)}$ 八蔽菏糖液 $(7-20 \%)$ 静脈內二注入 スル時八血糖過多フ来スモ, 15 分投二八既”正常

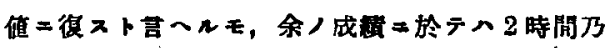

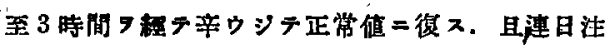

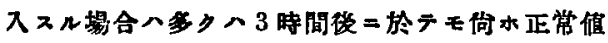

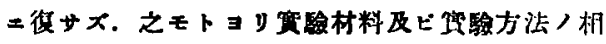

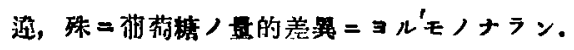

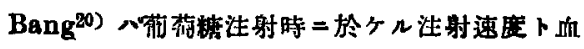

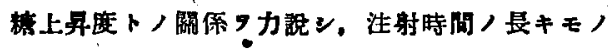

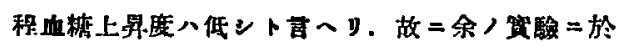
テヘ㲘进ノ如ク努ょテー定速度 , 1.

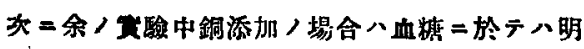

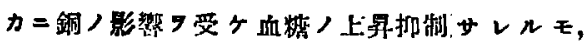

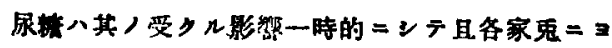

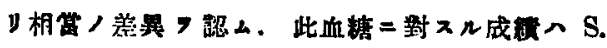
Ugsolzew，千菜氏䇰ノ成猜ト一致スル所ニシテ 


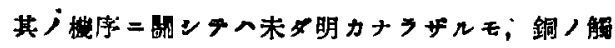
媒作用，或八銅 =ョル楉同化作用，促䢝，糖然烧

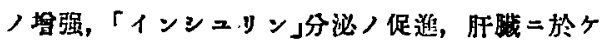
儿榶原要分解作用八抑制，絧狀織内被細胞系統卜 八聯關作用等 7 推考ス几ニ難カラ

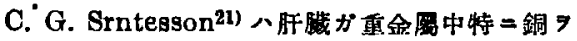

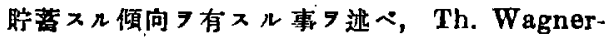

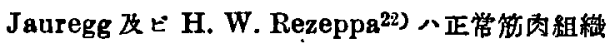

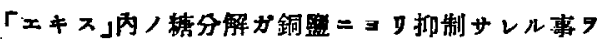

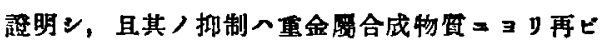
除カレ得几事の報告セり。

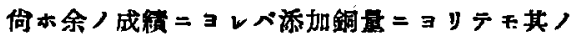

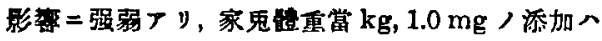
當 $\mathrm{kg}, 0.2 \mathrm{mg}$ /添加八堨合 3 其ノ影慗著明ナ y.

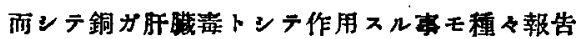

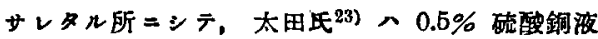
$1.7-3.0 \mathrm{cc} 71$ 日 $1-3$ 回家鬼静腿內注射

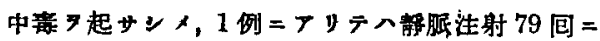

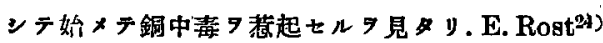
八0.3 乃至 $0.6 \mathrm{~g}$ ／如丰大量，硫酸銅 $=\exists y$ 始 火

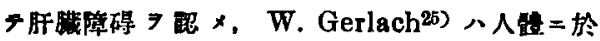

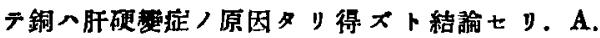
Hermann及ビ Müller26) モ銅中霖八稀ナリト进 今，大井手氏27)八銅投與二ヨ几家鬼肝/顆粒/沈

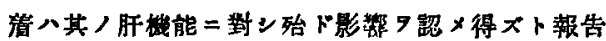
モ. H. Schnet\%, A. Morelli28) 何レも微

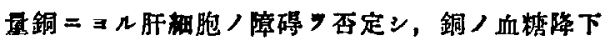

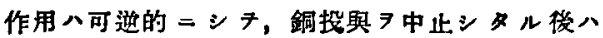
「ナドレナリン」ノ作用及ビ糖輸入 $=3$ 几過血糖八 再ビ出現スルコトラ簦明ン銅 $=ョ$ 血栯降下ガ肝

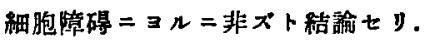

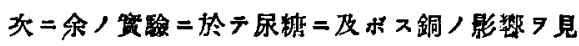

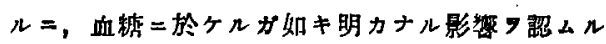
コト能ハザれモ，少クトモ一時的二八尿糖量/減

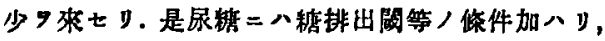

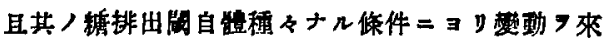

スタメ一定ノ明カナル俱向 9 示サザリンナラント 思考ス。坂口等29) $=3$ 等同一條件下 =於ヶn

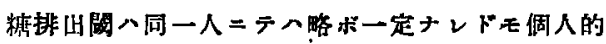
差暴ハカナリ著ンク，又同一人ニテモ佟件ノ楚化

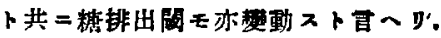

次二剔脾家鬼，場合

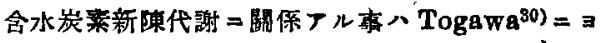
y始メテ詵明セラレタル所ニシテ剔脾動物ニ於テ

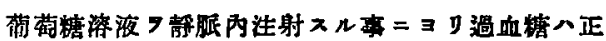

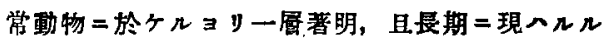

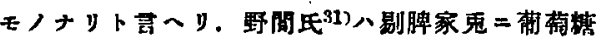
フ注入スル時八街後旬日間糖尿八着ンク强ク，且

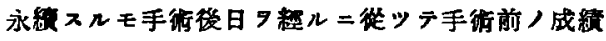

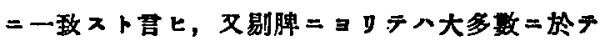

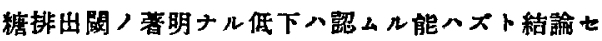

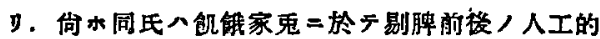

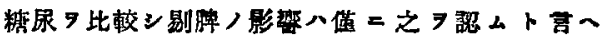

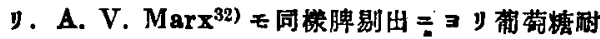

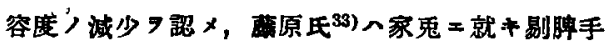
北

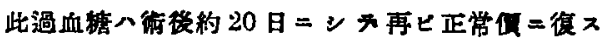

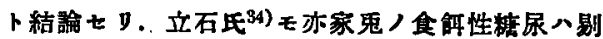

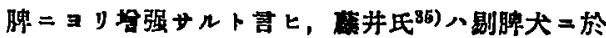

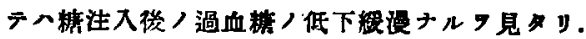
然 $=$ G. Montemartini ${ }^{86)}$ 八剔脾 $=a$ 血糖

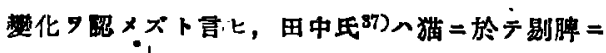

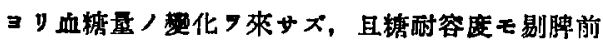

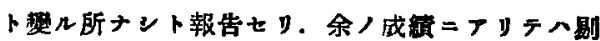

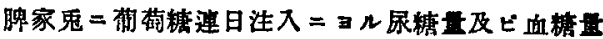
/推移八正常家鬼ノ埸合ト大差 7 㴓メズ，只耐糖 力減弱，傾向正常家兔二比ン嚾二大ナルモノ，如

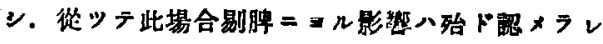

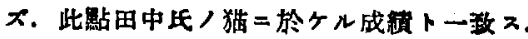

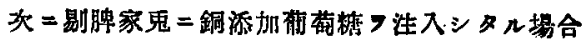

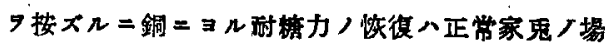

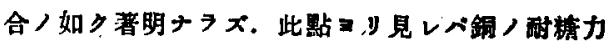

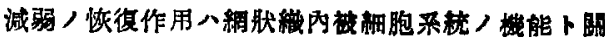


牧フィノノ如ン。

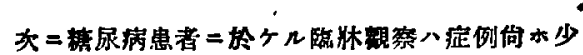

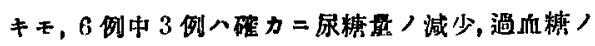

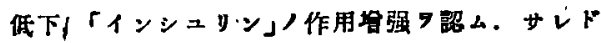

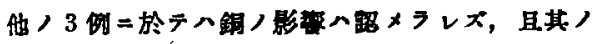

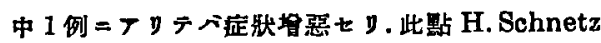
ノ如キ好成震 舉ダ得ザリキ，然レ共銅ノ影掏モ

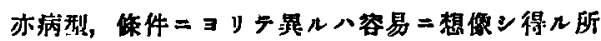
ナレベ, ュノ成縝

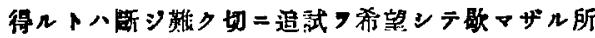
$+\boldsymbol{y}$.

\section{策5禁结論}

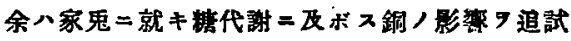
スルト共 $=6$ 例ノ糖尿病者 $=$ 就キ錎作用 7 检討 ン次ノ結論 7 得夕士。

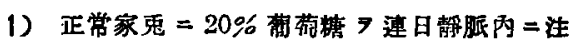

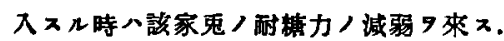

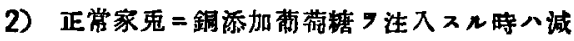

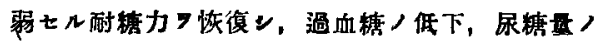

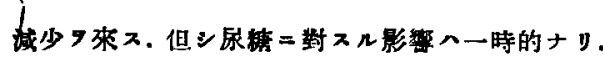

3）（2）八昜合添加 ス几銅量=3y其八影繁二 强弱厂リテ,銅量家兔镂更當 $\mathrm{kg}, 1.0 \mathrm{mg}$ ，添加八、

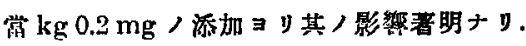

4) 剔脾家象二葡萄糖 7 浬日注入スル時八正常

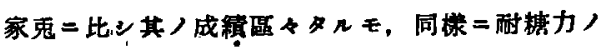
減易 7 來ス。

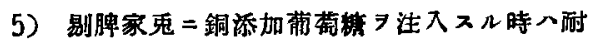
搪力ノ恢得へ正常家鬼/如ク著明ナラズ.

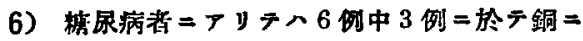

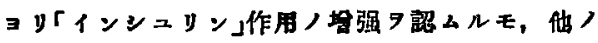

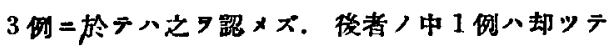
症狀罢をり。

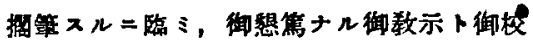

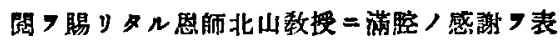

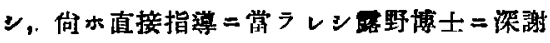

x.

(本諭文)一部八昭和 13 年 4 月 2 日旦本消

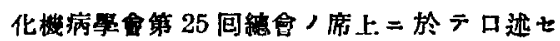
D).

\section{主 要 文}

1) G. Bertrand u. M. Macheboeuf, C. r. hebdom. des Séances de 1'Acad. des Siences Tom 182, Nr. 25. 1926. 2), F. Hendrych u. H. Weden, Handbuch d. exper. Pharmakologie. 3, 1934. 3) L. Tkachenko, Journ, of orient. med. Bd. 7, Nr. 213, 1927. z. n. Kongress. f. inn. Med. Bd. 49, 1928 4) $H$. Schnetz, Arch. f. exper. pathologie. 178, 1935 . 5) H. Häusler u. H. Schnetz, Biochemisch. Z. 275, 204, 1935. 6) D. A. Scott, Journ. of Pharmacol. 55, $1935 . \quad$ 7) $L$. Vogel, Arch. für exper. Path. u. Pharmakol. Bd. 183, 1936. 8) H. Handovsky, Arch. internant. Pharmacodynamie. 49, 1934. 9) $H . L$. Keil u. V. E. Nelson, Journ. of Biol.jChemie. 106, 1934. 10) S. Unolzew, Biochem. Z. 276, 1935. 11) $H$. Schnetz, Z. klin. Med. 129, 1936. 12) 千葉, 严

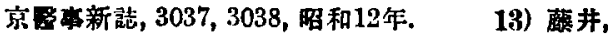
The Journ, of Biochemistry. Bd. 25, 2. 14) Hagedorn-Jensen, Biochemisch. Z. 135, 1923, 137. 1923. 15) 坂口, 吳, 坂本, 丙科書. 16) $H$. Schnetz, Klin. W. Nr. 19, 1937. 17) 長谷川, 日 本內科會誌，14，大正15年. 18）山川，日本內科會 誌，17，昭和4年，19)上田，Humoraldiagnose. 昭和7年. 20) I. Bang, Der Blutzucker. 1913. 91) C. G. Santesson, Skand. Arch. Physiolog. 61 u. 63, 1931. 22) Th. Wagner-Jauregg u. Ir. W. Rezeppa, Hoppe-Seyler's Z. 243, 1936. 23) 太 田，寅驗消化病，11，昭和11年. 24) E. Rost， Handbuch d. Lebensmittelehemie, Bd. 1, 1933, z. n. klin. W. Nr. 19. (H. Schnetz). 25) $W$. Gerlach, Schweiz. Med. Wschr. 1935. 36) $A$. Hermainn u. Müller, Ergeb. d. inn. Mediz. u. 
Kinderheilkunde, Bd. 48, $1935 .-271$ 大井手,

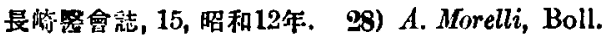
Soc. ital. Biol. sper. 13, 1938., z. n. Kongress. f. inn. Med. Bd.102. 29) 坂口, 川岛, 江田, 㞸

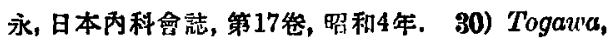
Biochem. Z. 109, 1920. 31) 野間，岡婜雜, 441, 大正15年. 32) A. V, Marx, klin. W achr. 9, 1930.
33）藤原，合数中央满院年瓡，昭和9年，34) 立石， - The Journ. of Biochemi. 21, $1935 . \quad 35)$ 藤弗, 岡豎雜，第47年，昭和10年. 33) G. Montemas'tini。 Poliklinico. sez. Chir. 36, 1929, z. n. Kongregszent. f. inn. Med. Bd.54. 37) 田中, The Tohoku Journ.of exper. medicine. 30.

Aus der Inneren Kitayama-Klinik der Medizinischen Fakultät Okayoma

(Direktor : Prof. Dr. K. Kitayama).

Über den Kinfluss ron Kupfer anf den Zuckerstoffwèchsel.

Von

Dr. T. Matuoka.

Eingegangen am 18. Juli 1948.

Bei Kaninchen hat der Verf. den Einfluss von Kupfer auf den Zuckerumsatz zu einer weiteren Prüfung unterzogen, um dann an Hand der 6 Fälle von Diabetikern die Wirkung des Kupfers festzustellen. Dadurch ist der Verf. zu folgendem Schluss gekommen :

1) Durch eine täglich vongenommene intra venöse Injektion 20\%iger Traubenzuckerlösung werden die betr. normalen Kaninchen an Zuckertoleranz herabgesetzt.

2) Durch die Traubenzuckereinführung mit Zusatz von Kupfer erholen sich die normalen .Kaninchen von der herabgesetzten Zuckertoleranz, indem die bestehende Hyperglykämie herabgeht und die Menge des Harnzuckers abninumt. Es sei erwähnt, dass die Wirkung dieser Injektion auf den Harnzucker unr von transitorischer Natur ist.

3) Die Wirkung dieser Injektion richtet sich nach der Grösse der zugefügten Kupfermenge. In der Dosis von $1,0 \mathrm{mg}$ pro Körperkilngramm zugesetzt ruft namentlich das Kupfer bei den betr. Kaninchen eine stärkere Wirkaung hervor als Zusatz in der Dosis von 0,2 mg pro Körkerkilogramm.

4) Wenn man splenektomierten Kaninchen Traubenzucker aufeinanderfolgend täglich injiziert, werden sie in der Zuckertolerenz herabgesetzt, wenn auch die Ergebnisse im Vergleich zu normalen Kaninchen Schwankungen unterworfen sind.

5) Durch die mit Kupferzusatz vorgenommene Injektion von Traubenzucker kommt? bei splenektomierten Kaninchen die herabgesetzte Zuckertoleranz nicht so bedeutendermassen zurück wie bei normalen Kaninchen der Fall ist.

6) Bei Diabetikern wird die Insulinwirkung in 3 von 6 Fällen durch die Einführung von Kupfer gesteigert, während in den übrigen 3 Fällen diese Steigerung nicht beobachtet wird. In einem dieser 3 Fälle wird die Krankhoit dadurch vielmehr verschlechtert. if 